\title{
Students' Knowledge Sharing Behaviours and Sense of Online Learning Community in Online Learning Environments
}

\author{
Cavit Erdoğmuş * \\ Amasya University, Graduate School of Natural and Applied Sciences, Department of \\ Computer Education and Instructional Technology, Amasya, Turkey
}

ORCID: 0000-0002-6717-0528

\author{
Recep Çakır \\ Amasya University, Education Faculty, Department of Computer Education and Instructional \\ Technology, Amasya, Turkey, \\ ORCID: 0000-0002-2641-5007
}

\author{
Özgen Korkmaz \\ Amasya University, Faculty of Enginneering-Architecture, Department of Computer \\ Engineering, Amasya, Turkey \\ ORCID: 0000-0003-4359-5692
}

Article history

Received:

06.07.2021

Received in revised form: 20.10.2021

Accepted:

27.10.2021

Key words:

Online learning;

Sense of community;

Knowledge sharing;

Distance learning
This study is conducted to find out the correlation between students' knowledge sharing behaviors and learning community feeling in online learning environments. Correlational survey model was conducted in this study. The study group is consisted of 139 participants (46 male, 93 female) who are enrolled in distance and undergraduate and associate degrees in the Distance Education Centre of Amasya University in Turkey. The Distance Education Centre uses LMS software. In this study, 9-question Personal Information Form was used to get the demographic information of the participants. With the help of a personal information form, the participants were asked about their gender, class, department, which devices they used for LMS, their weekly stay in the LMS and the number of logins to the LMS. Also, the Sense of Community in Online Learning Scale used to collection data. A total of 139 participants were reached during the 5-week data collection process. The collected data were analysed with SPSS 25.0 program. As a result, participants' sense of community in online learning and knowledge sharing behavior were high. There was a moderately positive relationship between sense of community in online learning and knowledge sharing behavior in online learning. Also, students' knowledge sharing behaviors and sense of community in online learning environment are affected by grade level, department, number of entry and online duration.

\footnotetext{
* Correspondency: caviterdogmus@gmail.com
} 


\section{Introduction}

Brown (2014) tried to understand how human shapes knowledge, how previous knowledge is retained, how new knowledge is obtained, synthesized, and integrated into permanent memory. While the debate on how learning is provided continues, a more modern variable has changed the direction of the discussion as it distinguishes technology, teacher, and student in terms of learning environment. Until recently, learning, physical interaction between learner and teacher have largely existed and been defined. The rapid increase of the world population and the advancement of technology increases the individuals' need for education and self-development. This leads to huge demand for learning. The lack of financial resources and also lack of efficient use of educational resources have led to new solutions and concepts other than the traditional methods used in education. Distance education is the most important one. Before addressing the topic of learning community (LC), it is helpful to define the term community. Cambridge Dictionary defines the community (2019) as "the people living in one particular area or people who are considered as a unit because of their common interests, social group, or nationality"

In another definition, community is defined as groups that create traditions and habits among themselves and trust each other in order to achieve the goals they have determined (Wilson \& Ryder, 1998). Westheimer and Kahne (1993) also described the concept of community as a process interaction between people who share benefits and commitment to common goals. The LC is defined by Bloomberg (2007) as the process of acquiring, creating, or transforming information. Moreover, the LC is often referred to as cooperative learning or a group that uses group-based pedagogies to promote community in the classroom (Kern \& Kingsbury, 2019). Shared goals, regular interaction with group members, diversity of views, a sense of belonging, a commitment to work together, a level of trust between participants, a sense of importance or the importance of people within the group, a set of common values, and finally, common goals in all groups reveal a LC (Byrd, 2016; Shackelford \& Maxwell, 2012; Exter, Korkmaz, Harlin, \& Bichelmeyer, 2009; Dawson, 2006; Rovai, 2002; Etzioni \& Etzioni, 1999). The definitions show that learning and community concepts are an integral part of each other.

With the spread of distance education, the lack of social relations between individuals is increasing in distance education and this shows that the demand for establishing interactive relations between both students and teachers has increased (Sun \& Chen, 2016). With new opportunities emerging for an increasingly affordable and accessible education, it is becoming increasingly difficult to create a meaningful sense of online learning community (SOOLC) that encourages students to learn. Looking in the literature, it has been widely recognized by researchers as a difficult but important task of online education to create a SOOLC (Sun \& Chen, 2016; Rockinson-Szapkiw, Pritchard, McComb-Beverage \& Schellenberg, 2013; Shen, Nuankhieo, Huang, Amelung \& Laffey 2008). While interaction is the most important necessity of online learning, many online students want to establish some contact with their peers, instructors, and counsellors (Drouin \& Vartanian, 2010; Exter et al, 2009). Researchers have made different suggestions so as to meet the demands of online learners. Methods such as active interaction, collaborative learning, social environment, sharing of resources in OLEs are supported and recommended (Palloff \&Pratt, 2007). Bielaczyc, Kate and Collins (1999) mentioned three scenarios that should be included in the activities to be implemented to enhance LCs. These are acquiring knowledge based on individual development and collaboration, sharing skills and knowledge among online learner, and provide a visible learning process. In addition, Haythornthwaite, Kazmer, Robins and Shoemaker (2000) proposed three teaching strategies to enhance SOOLC in distance education: to promote the 
first relationship, to observe and contribute interactivity and involvement, and to provide various communication ways. Bailey and Card (2009) stated that success during distance education will be achieved through emphasizing the establishment of good rapport amongst the relevant parties as well as through enhancing the communication between instructors and students, and also through the ability of instructors to empathize with students, teaching passion, and eagerness to help students succeed. Moreover, they stated that online instructors should be careful and timely in responding to students' emails and text messages (Bailey \& Card, 2009).

In my opinion, it would be helpful to talk about the benefits of a strong SOOLC. Research has shown that there is a positive correlation between a high SOOLC and learning engagement, learning, sense of belonging and student satisfaction (Trespalacios \& Perkins, 2016; Seckman, 2014; Liu, Magjuka, Bonk \& Lee, 2007). Students who reported a higher standard of SOOLC also said that they experienced higher levels of satisfaction in their social lives through the reduction of loneliness and stress in online programs (Elkins, Forrester \& Noel-Elkins, 2011). Gul and Arabac1 (2018) in their study with distance education graduate students stated that it would be beneficial to have more live lessons for the students in order to strengthen their SOOLC. The study by Rovai (2002) revealed that the conception of a high SOOLC created in distance learning environments supports effective learning. It is also emphasized that a high SOOLC within students in cognitive and social terms is important for the learning environment to be effective (Rovai et al. 2004).

Knowledge sharing (KS) is the process of mutual information sharing within the framework of trust between group members and reusing this information. (Garcia-Sánchez, Diaz-Diaz \& De Saá-Pérez, 2019; Chen \& Hung, 2010). With the help of KS, students can access various learning resources and create a collaborative learning environment (CLE). According to Booth (2012), due to shortage of somatic communication and confidence, online KS is difficult. Unlike face-to-face learning, online students cannot observe each other's facial expressions and cannot notice verbal and non-verbal cues, this makes difficult to create an atmosphere of mutual trust at online environment (Young \& Tseng, 2008; Ridings, Gefen \& Arinze, 2002). Group interactions are an effective process for creating and KS in online groups (Oliveira, Tinoca \& Pereira, 2011). However, online learning requires everyone to be on the same page for high confidence and active communication. Students often feel anxious at online work group and rebel at the idea of online group, which prevents students from sharing new information (Chang \& Kang, 2016). Therefore, the online learning program / course should be designed to enable maximize students' potential and responsibilities.

There are several factors that influence KS. In the research, psychological differences, environmental factors and used online applications are some of the factors (Collins, Salgado, and Cabrera, 2006). To support group members to share information easily, it is important to develop supportive and reassuring relationships and establish group norms with other group members in OLEs (Finegold \& Cooke, 2006; Pankoke-Babatz \& Jeffrey, 2002; Tu \& Corry, 2001). To develop a deeper relationship between students and the instructor can provide opportunity to interact with each other by discussing the questions at the topic (Cameron, Morgan \& Williams, 2011; Brindley, Walti \& Blaschke, 2009). This helps them get the chance to know each other on a personal level and encourages students to interact with each other through advice, opinions, and explanations (Morgan, Cameron \& Williams, 2009). In addition to all these, practices such as giving extra credit increase reciprocal trust between members and further enhance interactions and KS. (Kao, Lin \& Sun, 2008). Without meaningful interactions, it would be difficult for group members to produce information 
together (Kao, Lin \& Sun, 2008).

Obviously, the continued expansion of online education brings opportunities and challenges to both educators and students in the field of Education. While new opportunities for a lowcost and accessible education are emerging, it is increasingly difficult to create a sense of meaningful LC that encourages student learning (Beeson, Aideyan, O' Shoney, Bowes, Ansell, \& Peterson, 2019). As a result of this section, we see that there is a relation between SOOLC and KS in OLE. The aim of this study is to find out how the correlation between the behaviours of students sharing information in OLE and the SOOLC. For this purpose, the research questions are as follows:

1. What is the level of students' knowledge sharing behaviours (SKSB) and SOOLC in OLE?

2. Do SKSB and SOOL in OLEs differ according to grade level, department, number of entry and online duration?

3. Is there a relationship between KS in OLE and the SOOLC?

4. To what extent do students' sense of the online learning system predicted by entry and log on times?

5. To what extent do students' online knowledge sharing, system predicted by entry and $\log$ on times?

\section{Method}

\section{Research Design}

In this study, correlational survey model was conducted. During this research, data were collected using scales. The method determines the existence and / or the degree of change together between two or more variables is called the correlational model (Büyüköztürk, Kılıç Çakmak, Akgün, Karadeniz \& Demirel, 2016).

\section{Working Group}

The study group of this research is consisted of 139 students who are enrolled in distance and undergraduate and associate degrees at Amasya University in Turkey. The distribution of the participants is shown in Table 1.

Table 1. Participants According to Department, Gender and Grade Levels

\begin{tabular}{|c|c|c|c|c|c|c|c|c|c|}
\hline \multirow[b]{2}{*}{ Department } & & & \multicolumn{6}{|c|}{ Grade Level } & \multirow[b]{2}{*}{ Total } \\
\hline & & & $\begin{array}{l}\text { Grade } \\
(\mathrm{X})\end{array}$ & 1 & $\begin{array}{l}\text { Grade } \\
\text { (Y) }\end{array}$ & 2 & $\begin{array}{l}\text { Grade } \\
(\mathrm{Z})\end{array}$ & 3 & \\
\hline \multirow{3}{*}{ Theology (A) } & \multirow[b]{2}{*}{ Gender } & Female & 0 & & & & 14 & & 14 \\
\hline & & Male & 1 & & & & 27 & & 28 \\
\hline & Total & & 1 & & & & 41 & & 42 \\
\hline \multirow{2}{*}{ Child Development (B) } & Gender & Female & 16 & & 32 & & & & 48 \\
\hline & Total & & 16 & & 32 & & & & 48 \\
\hline \multirow{3}{*}{$\begin{array}{l}\text { Medical Documentation and } \\
\text { Secretariat }(C)\end{array}$} & \multirow[b]{2}{*}{ Gender } & Female & 16 & & 9 & & & & 25 \\
\hline & & Male & 1 & & 4 & & & & 5 \\
\hline & Total & & 17 & & 13 & & & & 30 \\
\hline Others (D) & Gender & Female & 4 & & 1 & & 1 & & 6 \\
\hline
\end{tabular}




\begin{tabular}{lllllll} 
& & Male & 9 & 4 & 0 & 13 \\
& Total & & 13 & 5 & 1 & 19 \\
\hline \multirow{3}{*}{ Total } & \multirow{2}{*}{ Gender } & Female & 36 & 42 & 15 & 93 \\
& & Male & 11 & 8 & 27 & 46 \\
& & & 47 & 50 & 42 & 139 \\
\hline
\end{tabular}

The habits of the participants to use the LMS system were obtained with the help of the personal information form. Considering the habits of the participants using the distance education system on a weekly basis. Number of entries are 28 participants $=1-3$ times, 39 participants $=4-6$ times and 72 participants $=7$ times and higher. In addition, the participants' $\log$ on times in the system is in the following way 107 participants=1-3 hours, 24 participants $=4-6$ hours and 8 participants $=7$ hours or more in a week.

\section{Data Collection Tools}

In this study, 9-question Personal Information Form was developed by the researchers to get the demographic information of the students. With the help of a personal information form, the participants were asked about their gender, class, department, which devices they used for LMS, their weekly stay in the LMS and the number of logins to the LMS. Live lessons, assignment and uploading of assignments, event planning and chat can be done via the LMS system. In addition, the following scales were used. Online Learning Community Feeling Scale, developed by Gökçearslan (2013), was used to measure the level of SOOLC of the study group. This scale was developed as a 4-Likert type with 28 questions. 17 of the scale items are positive and 11 items are negative. There are 3 factors in the scale: Compliance, Independence and Similarity. The scale variance is $42.65 \%$. The Cronbach alpha value was reported 0.88 . The Cronbach's alpha internal consistency coefficient is 0.89 for the first factor, 0.85 for the second factor, and 0.42 for the third factor. Although this value seems low for the third factor, it can be said that the reliability of the whole scale is high. The "Knowledge Sharing Behavior Scale in Online Learning Environments" (Avc1 \& Ergün, 2015) which was adapted from Knowledge Sharing Behavior Scale developed by Tseng and Kuo (2014), was used to measure the study group's behaviours to sharing information in OLEs. This scale was adapted to Turkish by Avc1 and Ergün in 2015. The scale developed as a 7-Likert consists of 2 sub-dimensions and 9 items such as Getting Information and Giving Information. Total variance of the scale was $71.9 \%$ and Cronbach's alpha value was 0.90 . The internal consistency coefficients of the factors in the scale were 0.91 and 0.87

The data were collected from the students enrolled in the Distance Education Centre of Amasya University. Distance Education Centre uses LMS software. The students were asked to answer the questionnaires and scales with the help of LMS. A total of 139 participants were reached during the 5-week data collection process.

\section{Data Analysis}

Two scales with different numbers of items and sub-dimensions were used to collect the data. SPSS 25.0 program was used to analyse collected data. Whether the obtained data was parametric or not was determined as a result of the analysis.

Table 2. Test of Normality 


\begin{tabular}{|c|c|c|c|c|c|}
\hline & \multicolumn{5}{|c|}{ Kolmogorov-Smirnov ${ }^{\mathrm{a}}$} \\
\hline & Statistic & $\mathrm{df}$ & $\mathrm{p}$ & Skewness & Kurtosis \\
\hline $\begin{array}{l}\text { Sense of Community } \\
\text { (SOC) }\end{array}$ & .080 & 139 & .028 & -.825 & 1.046 \\
\hline Knowledge Sharing & .072 & 139 & .073 & -.479 & -.137 \\
\hline
\end{tabular}

a. Lilliefors Significance Correction

Kolmogorov-Smirnov test result $\mathrm{p}>0.05$ was obtained. In addition, skewness and kurtosis values were found to be between \pm 1 . When these results are examined, the collected data show normal distribution (Büyüköztürk et al. 2016). A kurtosis value of \pm 1.0 is considered excellent, but a value between \pm 2.0 is also acceptable in most cases (George \& Mallery, 2010). Mean, standard deviation, independent sample t test, one-way ANOVA test, Pearson's correlation test and regression analysis conducted to find answers the research questions.

\section{Result}

Descriptive analysis findings of students' behaviours towards KS and SOOLC are summarized in Table 3.

Table 3. SKSB and SOOLC

\begin{tabular}{lllllll}
\hline Variable & & $\mathrm{N}$ & Minimum & Maximum & $\overline{\mathrm{X}}$ & S.D \\
\hline \multirow{4}{*}{ SOC } & Compliance & & 1.00 & 4.00 & 3.30 & .70817 \\
& Independence & & 1.25 & 4.00 & 3.3867 & .66379 \\
& Similarity & & 1.00 & 4.00 & 2.4317 & .78988 \\
& Total & & 1.47 & 4.00 & 3.04 & .49066 \\
\cline { 1 - 1 } KS & Getting Information & & 1.00 & 7.00 & 5.7374 & 1.26846 \\
& Giving Information & 1.00 & 7.00 & 4.1381 & 1.65325 \\
& Total & 1.38 & 7.00 & 4.9378 & 1.27590 \\
\hline
\end{tabular}

Looking at the Compliance sub-factor in Table 3, it is seen that $\bar{X}=3.30$. This result has been considered an above-average value. The higher mean may indicate that students' presence in learning environments increases their self-confidence. It can also be emphasized that the community believes they will support each other, improve their learning and working skills together, and be able to learn more comfortably. The Independence factor mean was found to be $\overline{\mathrm{X}}=3.3867$. Because this value is above mean, it can be assumed that students will feel comfortable, peaceful, and secure in the online learning community (OLC). In addition, students can be considered to encourage each other to learn in the LC, their communication will be strong, they can get support in solving the problems they face, and their communication skills will improve. The arithmetic mean value of the similarity factor was found to be $\bar{X}=2.4317$. The fact that the arithmetic average is lower than other factors may indicate that students do not feel the need-to-know the other members of their community. It can be concluded that it is not very important for members to have similarities such as social, cultural, academic and lifestyle.

When looking at Table 3, The Getting Information factor value is $\bar{X}=5.7374$. Given that the highest value is 7.00 , this finding may indicate that students are eager to learn. This means that students read and download from online environments to benefit from the experience, knowledge, and skills of other users. Likewise, it is observed that the Giving Information factor value is $\bar{X}=4.1381$. Although it was lower than the Getting Information factor, it was 
higher than average. It can be concluded that students feel comfortable sharing their feelings, experiences, knowledge, and skills. Moreover, the one-way ANOVA results on whether students' behaviours to sharing knowledge in OLEs and SOOLC differed based on grade level are summarized in Table 4 and Table 5.

Table 4. SKSB and SOOLC Descriptive Statistics by Grade Level

\begin{tabular}{llllll}
\hline & & Mean & Std. Deviation & Std. Error \\
\hline KS & 1. Grade & 47 & 5.3016 & 1.18602 & .17300 \\
& 2: Grade & 50 & 4.9315 & 1.29763 & .18351 \\
& 3. Grade & 42 & 4.5381 & 1.25432 & .19355 \\
Total & 139 & 4.9378 & 1.27590 & .10822 \\
& 1. Grade & 47 & 2.9741 & .43599 & .06360 \\
& 2: Grade & 50 & 3.0188 & .49939 & .07062 \\
& 3. Grade & 42 & 3.1389 & .53241 & .08215 \\
& Total & 139 & 3.0400 & .49066 & .04162 \\
\hline
\end{tabular}

Table 5. SKSB and SOOLC ANOVA Statistics by Grade Level

\begin{tabular}{llllllll}
\hline & & Sum of Squares & $\mathrm{df}$ & Mean Square & $\mathrm{F}$ & $\mathrm{p}$ & $\eta^{2}$ \\
\hline \multirow{3}{*}{ KS } & Between Groups & 12.932 & 2 & 6.466 & 4.154 & $.018^{*}$ & .058 \\
& Within Groups & 211.721 & 136 & 1.557 & & & \\
\hline \multirow{3}{*}{ SOC } & Total & 224.653 & 138 & & & & .019 \\
& Between Groups & .637 & 2 & .319 & 1.330 & .268 & \\
& Within Groups & 32.586 & 136 & .240 & & & \\
\hline
\end{tabular}

Table 5, there is a significant difference between the means of the $\operatorname{KS}\left(\mathrm{F}_{(2-136)}=4.154 ; \mathrm{p}<0.05\right)$. Levene test was used to understand whether the group distributions and variances were homogeneous. After this process, Post-Hoc was used to identify the groups that provided significant differences. As a result of this analysis, it was found that the variances were homogeneous. The Tukey multiple comparison technique, which is commonly used in case of variance homogeneity, was preferred. According to Tukey multiple comparison analysis results, there was a significant difference between 1st grades and 3rd grades at KS. The behaviours of 1 st grade level students $(\overline{\mathrm{X}}=5.3016)$ are significantly higher than 3rd grade level students $(\overline{\mathrm{X}}=4.5381)$. According to this finding, freshmen are able to share their emotions, knowledge, skills and experiences more comfortable in online environment. However, the analysis suggests that third-year students are more secretive about their sharing in OLEs. As a result of the grade level analysis of the SOOLC, there was no statistical difference between the arithmetic mean of the SOOLC. Because of this, it can be said that there are no differences between the belonging of different grade level students in their own online education environment and their relationship with group members. Table 6 and Table 7 summarizes the findings on whether SKSB and SOOLC differ according to the department.

Table 6. SKSB and SOOLC Descriptive Statistics by Department

\begin{tabular}{|c|c|c|c|c|c|}
\hline & & $\mathrm{N}$ & Mean & Std. Deviation & Std. Error \\
\hline \multirow[t]{5}{*}{$\mathrm{KS}$} & Theology Completion & 42 & 4.5673 & 1.24500 & .19211 \\
\hline & Child Development & 48 & 5.0260 & 1.13166 & .16334 \\
\hline & $\begin{array}{l}\text { Medical Documentation and } \\
\text { Secretarial }\end{array}$ & 30 & 4.9825 & 1.25549 & .22922 \\
\hline & Other & 19 & 5.4632 & 1.55912 & .35769 \\
\hline & Total & 139 & 4.9378 & 1.27590 & .10822 \\
\hline SOC & Theology Completion & 42 & 3.1433 & .53282 & .08222 \\
\hline
\end{tabular}




\begin{tabular}{|c|c|c|c|c|}
\hline Child Development & 48 & 3.0357 & .38028 & .05489 \\
\hline $\begin{array}{l}\text { Medical Documentation an } \\
\text { Secretarial }\end{array}$ & 30 & 2.8963 & .53156 & .09705 \\
\hline Other & 19 & 3.0493 & .55391 & .12708 \\
\hline Total & 139 & 3.0400 & .49066 & .04162 \\
\hline
\end{tabular}

Table 7. SKSB and SOOLC ANOVA Statistics by Department

\begin{tabular}{|c|c|c|c|c|c|c|c|}
\hline & & $\begin{array}{l}\text { Sum } \\
\text { Squares }\end{array}$ & of $\mathrm{df}$ & Mean Square & $\mathrm{F}$ & $\mathrm{p}$ & $\eta^{2}$ \\
\hline \multirow{3}{*}{ KS } & Between Groups & 11.444 & 3 & 3.815 & 2.415 & .069 & .051 \\
\hline & Within Groups & 213.209 & 135 & 1.579 & & & \\
\hline & Total & 224.653 & 138 & & & & \\
\hline \multirow{3}{*}{ SOC } & Between Groups & 1.070 & 3 & .357 & 1.497 & .218 & .032 \\
\hline & Within Groups & 32.154 & 135 & .238 & & & \\
\hline & Total & 33.223 & 138 & & & & \\
\hline
\end{tabular}

Findings of the ANOVA, there was no significant statistical difference in the arithmetic mean of the SKSB and SOOLC compared to the departments. It can be said that the departments that students study in do not have an effect on information sharing behaviour. Therefore, it can be assumed that the sections in which students take lessons do not differ in their SOOLC. Findings of whether SKSB and SOOLC differ according to the number of entries to the online system are summarized in Table 8 and Table 9.

Table 8. SKSB and SOOLC Descriptive Statistics by Number of Entry

\begin{tabular}{llllll}
\hline & & Mean & Std. Deviation & Std. Error \\
\hline KS & $1-3$ times & 28 & 3.8125 & 1.24185 & .23469 \\
& $4-6$ times & 39 & 4.9109 & 1.06235 & .17011 \\
& 7 times and more & 72 & 5.3899 & 1.12541 & .13263 \\
SOC & 139 & 4.9378 & 1.27590 & .10822 \\
& Total & 28 & 2.7246 & .59860 & .11313 \\
& $1-3$ times & 39 & 3.0032 & .38030 & .06090 \\
& 4-6 times & 72 & 3.1825 & .44009 & .05187 \\
\hline
\end{tabular}

Table 9. SKSB and SOOLC ANOVA Statistics by Number of Entry

\begin{tabular}{|c|c|c|c|c|c|c|c|}
\hline & & Sum of Squares & $\mathrm{df}$ & Mean Square & $\mathrm{F}$ & $\mathrm{p}$ & $\eta^{2}$ \\
\hline \multirow{3}{*}{$\mathrm{KS}$} & $\begin{array}{l}\text { Between } \\
\text { Groups }\end{array}$ & 50.203 & 2 & 25.102 & 19.569 & .000 & .223 \\
\hline & Within Groups & 174.450 & 136 & 1.283 & & & \\
\hline & Total & 224.653 & 138 & & & & \\
\hline \multirow{3}{*}{ SOC } & $\begin{array}{l}\text { Between } \\
\text { Groups }\end{array}$ & 4.301 & 2 & 2.151 & 10.113 & .000 & .123 \\
\hline & Within Groups & 28.922 & 136 & .213 & & & \\
\hline & Total & 33.223 & 138 & & & & \\
\hline
\end{tabular}

In Table 9, there are significant differences between the mean of the number of weekly entries to the online system of the students. There was a significant statistical difference between the mean $(\bar{X}=3.8125)$ of the student who entered the system 1-3 times and the mean $(\overline{\mathrm{X}}=4.9109)$ of the student who entered the system 4-6 times. This difference may highlight the result that students who gain more access to the system feel more comfortable and safer in sharing or accessing information in a learning environment. Likewise, there was a significant statistical difference between the mean of the student who entered the system 1-3 times $(\overline{\mathrm{X}}=3.8125)$ and the mean of the student who entered the system 7 times and above $(\bar{X}=5.3899)$. In the same 
way, we can say that with the increasing number of entries into the system, students are able to share information safely in online education environments and have access to information. Findings of whether SKSB and SOOLC differ according to the log on duration in the LMS are summarized in Table 10 and Table 11.

Table 10. SKSB and SOOLC Descriptive Statistics by Online Duration

\begin{tabular}{llllll}
\hline & & $\mathrm{N}$ & Mean & Std. Deviation & Std. Error \\
\hline KS & 1-3 hours & 107 & 4.8005 & 1.33658 & .12921 \\
& 4-6 hours & 24 & 5.3281 & .82545 & .16850 \\
& 7 hours and above & 8 & 5.6031 & 1.21900 & .43098 \\
SOC & Total & 139 & 4.9378 & 1.27590 & .10822 \\
& 1-3 hours & 107 & 2.9998 & .50991 & .04930 \\
& 4-6 hours & 24 & 3.1425 & .35640 & .07275 \\
& 7 hours and above & 8 & 3.2695 & .52030 & .18396 \\
\hline
\end{tabular}

Table 11. SKSB and SOOLC ANOVA Statistics by Online Duration

\begin{tabular}{llllllll}
\hline & & Sum of Squares & df & Mean Square & F & $\mathrm{p}$ & $\eta^{2}$ \\
\hline \multirow{3}{*}{ KS } & Between Groups & 9.216 & 2 & 4.608 & 2.909 & .058 & .041 \\
& Within Groups & 215.437 & 136 & 1.584 & & & \\
\hline \multirow{3}{*}{ SOC } & Total & 224.653 & 138 & & & & \\
& Between Groups & .846 & 2 & .423 & 1.776 & .173 & .025 \\
& Within Groups & 32.378 & 136 & .238 & & & \\
\hline
\end{tabular}

ANOVA findings, there was no significant statistical difference in the arithmetic mean of the SKSB and SOOLC compared to the duration of their stay in the system. Students' weekly stay in the online system has no effect on their KS behaviour or SOOLC. The findings regarding the relationship between KS in OLEs and the SOOLC are summarized in Table 12.

Table 12. Correlation Between KS in OLEs and SOOLC

\begin{tabular}{lllll}
\hline & & $\begin{array}{l}\text { Getting } \\
\text { Information }\end{array}$ & $\begin{array}{l}\text { Giving } \\
\text { Information }\end{array}$ & $\begin{array}{l}\text { Knowledge } \\
\text { Sharing }\end{array}$ \\
\hline \multirow{3}{*}{ Compliance } & $\mathrm{r}$ & $.556^{* *}$ & $.590^{* *}$ & $.659^{* *}$ \\
& $\mathrm{p}$ & .000 & .000 & .000 \\
& $\mathrm{~N}$ & 139 & 139 & 139 \\
\hline \multirow{3}{*}{ Independence } & $\mathrm{r}$ & $.431^{* *}$ & $.309^{* *}$ & $.415^{* *}$ \\
& $\mathrm{p}$ & .000 & .000 & .000 \\
& $\mathrm{~N}$ & 139 & 139 & 139 \\
\hline \multirow{2}{*}{ Similarity } & $\mathrm{r}$ & .084 & $.216^{*}$ & $.182^{*}$ \\
& $\mathrm{p}$ & .323 & .011 & .032 \\
\hline \multirow{3}{*}{ SOOLC } & $\mathrm{N}$ & 139 & 139 & 139 \\
& $\mathrm{r}$ & $.507^{* *}$ & $.539^{* *}$ & $.601^{* *}$ \\
& $\mathrm{p}$ & .000 & .000 & 000 \\
\hline **.Correlation is significant at the 0.01 level (2-tailed) & & 139 \\
*.Correlation is significant at the 0.05 level (2-tailed). & & \\
\hline
\end{tabular}

Table 12 shows a positive and above average correlation between the SOOLC and KS ( $\mathrm{p}<0.05, \mathrm{r}=0.601)$. Accordingly, students can be said to exhibit information sharing behaviours as they are safer and more comfortable as their SOOLC levels increase. When the factors of the two scales used in this study are examined, there is a similarly positive and above average correlation between the Compliance factor and the Getting Information $(\mathrm{p}<0.05, \mathrm{r}=0.556)$ and the Giving Information $(\mathrm{p}<0.05, \mathrm{r}=0.590)$ factors. According to this finding, as students increase their cohesion in their community, it can be assumed that they have no problems in accessing and sharing information. There is a positive correlation 
between the factor of Independence and the Getting Information factor ( $p<0.05, r=0.431$ ) and the Giving Information factor $(\mathrm{p}<0.05, \mathrm{r}=0.309)$. As the sense of independence increases in the community environment, it can be said that the students are comfortable in getting information and giving information. However, it can be thought that this comfort in information sharing behaviour is towards accessing information rather than giving information. In the same way, a positive and below-average correlation was found between the similarity factor and the inference factor $(\mathrm{p}<0.05, \mathrm{r}=0.216)$. If students have similar personal or social characteristics, they will be comfortable giving information in the community. The regression analysis results for the prediction of the SOOLC according to the number of entries the online system and online duration of the system are also summarized in Table 13.

Table 13. Regression Analysis Results of SOOLC Prediction Based on Entry and Log on Times

\begin{tabular}{lllllll}
\hline Variable & B & S.E & $\mathrm{t}$ & $\mathrm{p}$ & $\begin{array}{l}\text { Paired } \\
\mathrm{r}\end{array}$ & $\begin{array}{l}\text { Parti } \\
\text { al } \\
\mathrm{R}\end{array}$ \\
\hline Constant & & & & & & \\
Number of Entry & 2.443 & .139 & 17.541 & .000 & & \\
Online Duration & .211 & .050 & 4.186 & .000 & .338 & .334 \\
\hline
\end{tabular}

Sense of Online Learning Community $=2.443+0.211$ Entry Times +0.084 Log on Times; $R 2=0.137$

As a result of the analysis, total variance predicts the sense of online community, number of entry and online duration in the system by $13.7 \%$. It is estimated that the SOOLC will be affected in terms of the number of logins to the LMS system and the duration of use. As a result of the analysis, it is seen that this prediction was confirmed.

Table 14. Regression Analysis Results of KS in OLE Prediction Based on Entry and Log on Times

\begin{tabular}{lllllll}
\hline Variable & $\mathrm{B}$ & $\mathrm{S} . \mathrm{E}$ & $\mathrm{t}$ & $\mathrm{p}$ & $\begin{array}{l}\text { Paired } \\
\mathrm{r}\end{array}$ & $\begin{array}{l}\text { Partial } \\
\mathrm{R}\end{array}$ \\
\hline Constant & 2.949 & .343 & 8.599 & .000 & & \\
Number of Entry & .709 & .124 & 5.718 & .000 & .440 & .431 \\
Online Duration & .269 & .172 & 1.561 & .121 & .133 & .118 \\
\hline
\end{tabular}

$K S$ in Online Learning Environment $=2.949+0.709$ Entry Times +0.269 Log on Times; $22=0.226$

As a result of the analysis, total variance predicts the KS in OLE, number of entry and online duration in the system by $22.6 \%$. It is estimated that the KS will be affected in terms of the number of logins to the LMS system and the duration of use. As a result of the analysis, it is seen that this prediction was confirmed.

\section{Discussion and Conclusion}

Students' feelings towards the OLC and their behaviours towards sharing knowledge were high. The findings were also supported by research in the literature (Enfiyeci \& Büyükalan, 2019; Er \& Saraç, 2017). Another study showed that attitudes towards the SOOLC were high (Ergün \& Kurnaz, 2017). Geçer and Dağ (2012); Pereira et al. (2007); Ruiz, Mintzer and Leipzig, (2006) stated that students are as happy as they are in traditional learning environments in OLEs. Ilgaz (2013) found that students with a high SOOLC were satisfied with online courses. There are similar results between the findings and the studies conducted in the literature. 
The gender variable did not make a statistical difference between students' SOOLC and online KS behaviours. Enfiyeci and Büyükalan Filiz (2019) obtained parallel results in their study among the students doing post-graduate education. Moreover, Lewis, Mcvay-Dyche, Chen, \& Soto (2015) found that gender variable had no significant effect on SOC and sharing information behaviours. Results in the literature are parallel with the findings in this study according to sense of online community by gender (Beeson, et al., 2019; Öztürk \& Deryakulu, 2011; Öztürk, 2009). However, as a result of the online interview conducted by Lewis et al. (2015) it was emphasized that the gender variable enriched and increased KS.

A significant result was not reached according to the grade level of the SOOLC. However, the descriptive results are above the average. In Byrd (2016)'s study of Amridge University on doctoral students, they noted that the fact that students complete their doctoral program together contributes positively to the SOC. Accordingly, students' grade level do not differ on students' community feelings. However, results showed that students who are educated in lower classes are more open to share information than students who are educated in upper classes.

The Independence factor is significantly differed according to studied department. Another study supporting this result was conducted with 453 students participate distance education Master's program at Gazi University (Enfiyeci \& Büyükalan, 2019). In another study, it was stated that the sense of online community of the participants in the same profession were higher (Lewis et al. 2015). These results indicate that the people with similar social characteristics can communicate more easily and feel more comfortable with each other. On the other hand, the Giving Information factor significantly differs according to studied department. Likewise, Areekkuzhiyil (2019) found a significant difference between the graduate students with different fields in his study.

The Compliance factor and the Independence factor have statistically significant difference according to entry times. Hovewer, Ergün and Kurnaz (2017) could not find any significant difference in their study. Scale difference could be the reason for different results. As a matter of fact, Dawson (2006) stated that online participation and the frequency of using online system create a meaningful relationship between students in terms of SOC. Increasing the amount of time spent in online environments increases the community sense of students and has the potential to provide teaching opportunities. Likewise, when used appropriately, online programs are thought to develop a SOC and a guiding presence to improve student outcomes (Mcclannon, Cheney, Bolt, \& Terry, 2018).

Moreover, the difference between the means of the Getting Information factor and Giving Information factor are significant according to entry times. It has been concluded that increasing entry times increases the behaviours of sharing information. Similarly, adequate interaction between users supports students' KS and increase learning efficiency (Chao, Hwu \&Chang, 2011).

It also showed a positive and above-average relationship between the SOOLC and KS. Chang (2018) stated in his study that the sense of the online community is high and the establishment of trust among students increases the ability of students to share information with each other at the online environment. Ardichvili (2008) stated that the high SOC in the online community increases the sharing of knowledge among students and increases their participation in the OLE. Aydın \& Gümüş (2016) found a moderate correlation between teamwork achievement and the SOC. This study shows that the SOOLC has positive effects 
on KS.

Another important result pertains to the following: sense of online community, entry times and $\log$ on times together predict the $13.7 \%$ of the total variance. Dawson (2006) emphasized that with the increase in the participation of students in online classes, their interaction with each other also increased, and their online community feelings also increased. Similarly, he stated that increasing in entry times increases the sense of online community (Dawson, 2006), and this increase seems to facilitate KS among students (Chao, Hwu \& Chang, 2011; Ardichvili, 2008; Chang, 2008).

This research is a study on students who have undergraduate and associate degree education with distance education. This study was carried out by working with a sample group that was too small to generalize. Therefore, it is recommended to repeat the study using a larger sample group in order to obtain more detailed and comprehensive information. By using both scales separately, experimental research can be used to interpret the effects of the results obtained on both scales in learning. LMS lengths of stay and entry numbers are assumed to be only $13.7 \%$ of the factors affecting SOOLC. For this, studies can be carried out on the assumption of what other factors affect SOOLC and how much they affect it. Similarly, it is assumed that LMS length of stay and entry numbers are only $22.6 \%$ of the factors affecting KS. For this, studies can be conducted on the assumption that other factors affecting KS are and how much they affect it

\section{References}

Ardichvili, A. (2008). Learning and knowledge sharing in virtual communities of practice: motivators, barriers, and enablers. Advances in Developing Human Resources. 10. 541-554.

Areekkuzhiyil, S. (2019). Attitude towards Knowledge Sharing among Under Graduate Students in Kerala. Institute of Advanced Study in Education (IASE), 18(7), 25-31.

Avc1, Ü. Y., \& Ergün, E. (2015). Adaptation of the knowledge sharing behavior in online learning environments scale to Turkish: A validity and reliability study. Baskent University Journal of Education, 2(2), 219-228.

Aydin, I. E., \& Gümüş, S. (2016). Sense of classroom community and team development process in online learning. Turkish Online Journal of Distance Education, O(0).

Bailey, C. J., \& Card, K. A. (2009). Effective pedagogical practices for online teaching: Perception of experienced instructors. The Internet and Higher Education, 12(3-4), 152-155.

Beeson, E. \& Aideyan, Babatunde \& Shoney, C. \& Bowes, D.A. \& Ansell, K.L. \& Peterson, H.M. (2019). Predicting sense of community among graduate students in a distance learning environment. Universal Journal of Educational Research, 7. 746-753.

Bielaczyc, Kate \& Collins, A.. (1999). Learning communities in classrooms: A reconceptualization of educational practice. Instructional-design theories and models: A new paradigm of instructional theory. pp. 269-292, Mahwah, NJ: LEA

Bloomberg, L. D. (2007). Culture and community: Case study of a video-conference graduate distance education program. Journal of Distance Education, 22(1), 41-58.

Booth, S. E. (2012). Cultivating Knowledge Sharing and Trust in Online Communities for Educators. Journal of Educational Computing Research, 47(1), 1-31.

Brindley, J., Blaschke, L. M., \& Walti, C. (2009). Creating Effective Collaborative Learning Groups in an Online Environment. The International Review of Research in Open and Distributed Learning, 10(3). 
Brown, L. (2014). Constructivist Learning Environments and Defining the Online Learning Community. i-Managers Journal on School Educational Technology, 9(4), 1-6.

Büyüköztürk, Ş., Kılıç Çakmak, E., Akgün, Ö.E., Karadeniz, Ş. \& Demirel, F. (2016). Scientific Research Methods in Education. 21. Pub, Ankara: Pegem Akademi.

Byrd, J. (2016). Understanding the Online Doctoral Learning Experience: Factors that Contribute to Students Sense of Community. The Journal of Educators Online, 13(2).

Chang, B., \& Kang, H. (2016). Challenges facing group work online. Distance Education, 37(1), 73-88.

Chang, B. (2018). Active Knowledge Sharing in Online Group Work. New Horizons in Adult Education and Human Resource Development, 30(3), 41-59.

Chen, C.-J., \& Hung, S.-W. (2010). To give or to receive? Factors influencing members' knowledge sharing and community promotion in professional virtual communities. Information \& Management, 47(4), 226-236.

Chao, C.-Y., Hwu, S-L. \& Chang, C-C. (2011). Supporting interaction among participants of online learning using the knowledge sharing concept. Turkish Online Journal of Educational Technology. 10(4). 311-319.

Collins, William \& Salgado, Jesus. (2006). Determinants of Individual Engagement in Knowledge Sharing. The International Joumal of Human Resource Management, 17(2), 245-264.

COMMUNITY: meaning in the Cambridge English Dictionary. (N.d.). Retrieved October 18, 2019, from https://dictionary.cambridge.org/dictionary/english/community.

Dawson, S. (2006). A study of the relationship between student communication interaction and sense of community. The Internet and Higher Education, 9(3), 153-162.

Drouin, M., \& Vartanian, L. R. (2010). Students' feelings of and desire for sense of community in face-to-face and online courses. The Quarterly Review of Distance Education, 11(3), 147-159.

Elkins, D. J., Forrester, S. A., \& Noel-Elkins, A. V. (2011). Students' perceived sense of campus community: The influence of out-of-class experiences. College Student Journal, 45(1), 105-121.

Enfiyeci, T, Büyükalan Filiz, S. (2019). An investigation of the variance of community students in distance education. Journal of TUBAV Science, 12 (1), 20-32.

Er, F. ve Saraç, B. (2017). Information sharing behaviors of students enrolled in Anadolu University Open Education System in online learning environments. Açıöğretim Uygulamaları ve Araştırmalart Dergisi[Journal of Open Education Practices and Research], 3(3), 47-63.

Ergün, E., Kurnaz, F.B. (2017). The Relationship Between Student Engagement and Sense of Community in Online Learning Environments. Kastamonu Educational Journal, 25(4), 1515-1532

Etzioni, A. E. O. (1999). Face-to-Face and Computer-Mediated Communities, A Comparative Analysis. The Information Society, 15(4), 241-248.

Exter, M. E., Korkmaz, N., Harlin, N. M., \& Bichelmeyer, B. A. (2009). Sense of community within a fully online program. The Quarterly Review of Distance Education, 10(2), 177-194.

Finegold, A. R., \& Cooke, L. (2006). Exploring the attitudes, experiences and dynamics of interaction in online groups. The Internet and Higher Education, 9(3), 201-215.

Garcia-Sánchez, P., Diaz-Diaz, N. L., \& De Saá-Pérez, P. (2019). Social capital and knowledge sharing in academic research teams. International Review of Administrative Sciences, 85(1), 191-207.

Geçer, A., \& Dağ, F. (2012). A blended learning experience. Educational Sciences: Theory and Practice, 12(1), 425-442. 
George, D., \& Mallery, M. (2010). SPSS for Windows Step by Step: A Simple Guide and Reference, 17.0 update (10a ed.) Boston: Pearson

Gökçearslan, Ş. (2013). Developing a Scale for the Sense of Community in Online Learning: A Validity and Reliability Study. Turkish Librarianship, 27(1),154-165.

Gül, İ., Arabac1, İ. B. (2018). Opinions Regarding the Program of Graduate Students in Educational Administration in Distance Education. Ordu University Journal of Social Science Research, 8(1), 79-88.

Haythornthwaite, C., Kazmer, M. M., Robins, J. and Shoemaker, S. (2000), Community Development Among Distance Learners: Temporal and Technological Dimensions. Journal of Computer-Mediated Communication, 6.

Ilgaz, H. (2013). The contribution of technology acceptance and community feeling to learner satisfaction in distance education. Procedia - Social and Behavioral Sciences, 106, 2671-2680

İşman, Aytekin (1998). Uzaktan Eğitim [Distance Education]. Değişim Pub. Sakarya.

Lewis, K., Mcvay-Dyche, J., Chen, H., \& Soto, T. (2015). Examining Sense of Community among Medical Professionals in an Online Graduate Program. The Journal of Educators Online, 12(1).

Kao, G.Y., Lin, S.S., \& Sun, C. (2008). Beyond Sharing: Engaging Students in Cooperative and Competitive Active Learning. Educational Technology \& Society, 11, 82-96.

Kern, B., \& Kingsbury, T. (2019). Curricular Learning Communities and Retention. Journal of the Scholarship of Teaching and Learning, 19(1).

Liu, X., Magjuka, R. J., Bonk, C. J., \& Lee, S. (2007). Does sense of community matter? An examination of participants' perceptions of building learning communities in online courses. The Quarterly Review of Distance Education, 8(1), 9-24.

Mcclannon, T. W., Cheney, A., Bolt, L., \& Terry, K. (2018). Predicting Sense of Presence and Sense of Community in Immersive Online Learning Environments. Online Learning, 22(4).

Moore, Michael G \& Kearsley, Greg, (2005). Distance education: a systems view of online learning. Wadsworth Cengage Learning, Belmont, CA

Morgan, K., Cameron, B. A., \& Williams, K. C. (2009). Student perceptions of social task development in online group project work. Quarterly Review of Distance Education, $10(3), 285-294$.

Odabaş, Hüseyin (2003). Internet Based Distance Education and Departments of Information and Records Management. Turkish Librarianship, 17(1).

Oliveira, I., Tinoca, L., \& Pereira, A. (2011). Online group work patterns: How to promote a successful collaboration. Computers \& Education, 57(1), 1348-1357.

Öztürk, E. (2009). The effect of type of computer mediated communication tools and virtual guests on social and cognitive presence in online learning community. Ankara University Institute of Educational Sciences. Ankara. PhD Thesis (Unpublished).

Öztürk, E., \& Deryakulu, D. (2011). The effect of type of computer mediated communication tools on social and cognitive presence in online learning community. H. U. Journal of Education, 41, 349-359.

Palloff, R. M., \& Pratt, K. (2007). Building online learning communities: effective strategies for the virtual classroom. San Francisco, CA: John Wiley \& Sons.

Pankoke-Babatz, U., \& Jeffrey, P. (2002). Documented Norms and Conventions on the Internet. International Journal of Human-Computer Interaction, 14(2), 219-235.

Pereira, J. A., Pleguezuelos, E., Merí, A., Molina-Ros, A., Molina-Tomás, M. C., \& Masdeu, C. (2007). Effectiveness of using blended learning strategies for teaching and learning human anatomy. Medical Education, 41(2), 189-195. 
Rockinson-Szapkiw, A. J., Pritchard, T., Mccomb-Beverage, S., \& Schellenberg, R. (2013). Promoting professional identity: a within group comparison of wiki-based and traditional assignments on school counselling students learning, sense of community and computer anxiety. British Journal of Guidance \& Counselling, 41(5), 559-572.

Rovai, A. P. (2002). Sense of community, perceived cognitive learning, and persistence in asynchronous learning networks. The Internet and Higher Education, 5(4), 319-332.

Rovai, A. P., Wighting, M. J., \& Lucking, R. (2004). The Classroom and School Community Inventory: Development, refinement, and validation of a self-report measure for educational research. The Internet and Higher Education, 7(4), 263-280.

Ridings, C. M., Gefen, D., \& Arinze, B. (2002). Some antecedents and effects of trust in virtual communities. The Journal of Strategic Information Systems, 11(3-4), 271-295.

Seckman, C. A. (2014). Perceived Sense of Community, Cognitive Engagement, and Learning Outcomes Among Undergraduate Nursing Students Enrolled in an InternetBased Learning Course. CIN: Computers, Informatics, Nursing, 32(10), 490-491.

Shackelford, J. L., \& Maxwell, M. (2012). Sense of community in graduate online education: Contribution of learner to learner interaction. The International Review of Research in Open and Distributed Learning, 13(4), 228-249.

Shen, D., Nuankhieo, P., Huang, X., Amelung, C., \& Laffey, J. (2008). Using Social Network Analysis to Understand Sense of Community in an Online Learning Environment. Journal of Educational Computing Research, 39(1), 17-36.

Simonson, Smaldino, S., \& Zvacek, S. (2015). Teaching and learning at a distance: foundations of distance education. Charlotte, NC: Information Age Publishing.

Sun, A., \& Chen, X. (2016). Online Education and its effective practice: a research review. Journal of Information Technology Education: Research, 15, 157-190.

Trespalacios, J., \& Perkins, R. (2016). Sense of community, perceived learning, and achievement relationships in an online graduate course. Turkish Online Journal of Distance Education, 17(3), 31-49.

Tseng, F.-C., \& Kuo, F.-Y. (2014). A study of social participation and knowledge sharing in the teachers online professional community of practice. Computers \& Education, 72, $37-47$.

Tu, C. H., \& Corry, M. (2001). A paradigm shift for online community research. Distance Education, 22(2), 245-263.

Uşun, Salih (2006). Uzaktan Eğitim [Distance Education]. Ankara: Nobel Pub.

Westheimer, J., \& Kahne, J. (1993). Building school communities: An experience based model. Phi Delta Kappan, 75(4), 324-328.

Williams, K. C., Morgan, K., \& Cameron, B. A. (2011). How do students define their roles and responsibilities in online learning group projects? Distance Education, 32(1), 4962.

Wilson, B., \& Ryder, M. (n.d.). Dynamic learning communities: An alternative to designed instructional systems. Retrieved November 5, 2019, from https://files.eric.ed.gov/fulltext/ED397847.pdf.

Young, M.-L., \& Tseng, F.-C. (2008). Interplay between physical and virtual settings for online interpersonal trust formation in knowledge-sharing practice. CyberPsychology \& Behavior, 11(1), 55-64. 